\title{
ANALISIS PENGARUH BOOK-TAX DIFFERENCES DAN LIKUIDITAS TERHADAP PERTUMBUHAN LABA (Pada Perusahaan Manufaktur Subsektor Industri Dasar Dan Kimia Yang Terdaftar Di Bursa Efek Indonesia Periode 2012-2015)
}

\author{
Hj. Asmaul Husna1 (asmaulhusna1771@gmail.com) \\ Fakultas Ekonomi Universitas Maritim Raja Ali Haji \\ Fatahurrazak² (razaknawawi@yahoo.com) \\ Fakultas Ekonomi Universitas Maritim Raja Ali Haji \\ Ratna Sari ${ }^{3}$ (Ratna.sa64@gmail.com) \\ Alumni Fakultas Ekonomi Universitas Maritim Raja Ali Haji
}

\begin{abstract}
ABSTRAK
Tujuan dari penelitian ini adalah untuk menganalisis pengaruh book-tax differences dan likuiditas terhadap pertumbuhan laba. Book-tax differences dalam penelitian ini diwakili oleh perbedaan permanen dan perbedaan temporer. Kemudian likuiditas dalam penelitian ini diwakili oleh working capital to total asset (WCTA). Objek penelitian ini adalah perusahaan manufaktur subsektor industri dasar dan kimia yang terdaftar di Bursa Efek Indonesia periode 2012-2015. Populasi berjumlah 64 perusahaan, dengan metode pemilihan sampel yaitu purposive sampling dan diperoleh total sampel sebanyak 16 Perusahaan. Metode penelitian adalah metode analisis dengan pendekatan kuantitatif. Hasil penelitian menunjukkan bahwa perbedaan permanen dan working capital to total asset berpengaruh terhadap pertumbuhan laba, sedangkan perbedaan temporer tidak berpengaruh terhadap pertumbuhan laba pada perusahaan industri dasar dan kimia yang terdaftar di Bursa Efek Indonesia periode 2012-2015.
\end{abstract}

\section{PENDAHULUAN}

Didalam dunia bisnis perusahaan dengan kondisi laba tentu saja merupakan hal yang menarik bagi stakeholder, jika dibandingkan dengan perusahaan yang mengalami kerugian.Laba merupakan indikator yang sangat penting dalam menilai kinerja keuangan suatu perusahaan, yaitu baik penilaian dari pihak internal maupun eksternal, yang mana hal tersebut guna mendukung keberlanjutan perusahaan.Mengenai pentingnya laba perusahaan bagi pengguna laporan keuangan, maka perusahaan harus mampu menyajikan informasi laba yang berkualitas. Informasi laba yang berkualitas adalah laba yang dapat mencerminkan pertumbuhan laba dimasa yang akan datang.

Pertumbuhan laba yang baik menunjukkan keuangan perusahaan yang baik, yang berguna untuk menaikkan nilai perusahaan. Karena yang menjadi sorotan utama bagi stakeholder seperti investor, kreditor, dan pembuat kebijakan akuntansi sebagai dasar dalam pengambilan keputusan,seperti pengukur prestasi atau kinerja manajemen perusahaan, pemberian kompensasi dan bonus bagi manajer, pemberian kredit bagi perusahaan, dan juga bagi pemerintah dalam hal ini informasi laba perusahaan digunakan sebagai dasar penentuan 
pengenaan pajak kepada perusahaan, khususnya instansi pemerintah yang terkait seperti direktorat jenderal pajak.Peneliti menggunakan pertumbuhan laba sebagai variabel penelitian karena laba merupakan dasar yang paling diperhatikan stakeholder dalam menilai kinerja keuangan perusahaan.

Pertumbuhan laba perusahaan dipengaruhi oleh beberapa faktor salah satunya yaitu book-tax differences. Book tax differences dapat mempengaruhi pertumbuhan laba karena menjadi suatu fenomena bagi manajer untuk melakukan praktik manajemen laba yang bertujuan untuk menghindari penurunan dan kerugian laba atau dengan kata lain mencegah agar pertumbuhan laba tidak menurun (Ningsih, 2010). Book-tax differences ini merupakan keadaan dimana adanya perbedaan dalam perhitungan laba menurut laporan keuangan komersial yaitu sesuai dengan ketetapan Standar Akuntansi Keuangan Akuntansi (SAK), dan menurut laporan keuangan fiskal yaitu dengan ketetapan peraturan perpajakan yang menyebabkan perbedaan laba akuntansi dengan laba fiskal. Perbedaan tersebut terbagi menjadi dua komponen yaitu perbedaan permanen (permanent differences) dan perbedaan temporer (temporary differences). Perbedaan permanenterjadi karena transaksi - transaksi pendapatan dan biaya diakui menurut akuntansi komersial dan tidak diakui menurut fiskal. Perbedaan tetap mengakibatkan laba menurut akuntansi berbeda (secara tetap) dengan penghasilan kena pajak menurut fiskal. Sedangkan perbedaan temporer terjadi karena perbedaan waktu pengakuan pendapatan dan biaya antara pajak dengan akuntansi.Suatu biaya atau penghasilan telah diakui menurut akuntansi komersial dan belum diakui menurut fiskal, atau sebaliknya.

Perbedaan permanen dan perbedaan temporer sebagai pembentuk book tax differences dalam mempengaruhi pertumbuhan laba yaitu kedua komponen ini menyebabkan adanya koreksi fiskal baik positif maupun negatif. Koreksi positif menyebabkan laba fiskal bertambah. Jika laba fiskal bertambah maka beban pajak yang harus dibayarkan akan semakin besar. Semakin besar beban pajak yang harus dibayarkan maka semakin kecil laba bersih yang dihasilkan.Koreksi negatif menyebabkan laba fiskal berkurang sehingga beban pajak yang harus dibayarkan semakin kecil.Beban pajak yang semakin kecil membuat laba bersih menjadi semakin besar (Rosanti, 2013).

Faktor lain yang mempengaruhi pertumbuhan laba perusahaan adalah likuiditas. Menurut Hery (2016:151), informasi likuiditas dapat memberikan informasi mengenai kinerja keuangan perusahaan selama periode tertentu. Melalui informasi likuiditas, pihak manajemen dapat memantau ketersediaan jumlah kas khususnya terkait dengan pemenuhan kewajiban yang akan segera jatuh tempo. Selain pihak internal perusahaan, informasi likuiditas juga berguna bagi pihak eksternal perusahaan seperti investor dalam hal pembagian dividen tunai atas investasi yang telah dilakukan, selain itu kreditor juga sangat berkepentingan dengan informasi likuiditas perusahaan dalam dasar pertimbangan pemberian kredit kepada perusahaan guna memperhitungkan kemampuan perusahaan dalam menghasilkan laba untuk mengembalikan pokok pinjaman beserta bunga yang akan didapatkan. Karena investor maupun kreditor biasanya akan menginvestasikan modal dan memberikan pinjaman atau kredit kepada perusahaan yang memiliki tingkat likuiditas yang baik.

Dalam penelitian ini, peneliti menggunakan working capital to total asset yang mewakili rasio likuiditas yang merupakan modal bersih dari total asset perusahaan. Di dalam Purnama, Pratomo dan Priyanto (2016), dimana penambahan modal kerja didapatkan dari pinjaman perusahaan, dan modal kerja tersebut digunakan perusahaan untuk kegiatan operasional. Dengan modal kerja yang besar perusahaan dapat meningkatkan aset yang dimiliki 
perusahaan sehingga kegiatan operasional perusahaan dapat berjalan semakin baik. Kegiatan operasional yang baik akan meningkatkan penjualan perusahaan sehingga kemampuan perusahaan dalam menghasilkan laba juga akan meningkat.

Telah banyak penelitian tentang pertumbuhan laba dilakukan, salah satunya penelitian tentang pengaruh book-tax differences terhadap pertumbuhan laba yang dilakukan oleh Windarti (2014) yang menyatakan bahwa perbedaan permanen dan perbedaan temporer berpengaruh positif terhadap pertumbuhan laba. Namun penelitian yang dilakukan oleh Lestari (2011) menyatakan hasil tidak konsisten yaitu menunjukkan bahwa perbedaan permanen dan perbedaan temporer tidak berpengaruh secara signifikan terhadap pertumbuhan laba. Dalam penelitian yang lain, mengenai pertumbuhan laba juga didilakukan oleh Purnama, Pratomo dan Triyanto (2016) yang menyatakan bahwa secara parsial bahwa variabel book-tax differences dengan proksi perbedaan permanen berpengaruh secara positif signifikan terhadap pertumbuhan laba, sedangkan perbedaan temporer dan working capital to total asset tidak berpengaruh terhadap pertumbuhan laba. Kemudian dalam penelitiannya Yusuf (2013) menyatakan bahwa working capital to total asset secara parsial berpengaruh positif signifikan terhadap perubahan laba.

Berdasarkan data yang diperoleh peneliti pada tahun 2015 yaitu Direktur Eksekutif Federasi Industri Kimia Indonesia (FIKI), mengatakan saat ini industri dalam negeri tengah mengalami tekanan yang besar, tantangan itu diantaranya adalah depresiasi rupiah terhadap dollar, kenaikan tarif listrik, kenaikan upah buruh, dan masuknya produk impor. Hal ini semua berdampak pada perlambatan pertumbuhan industri terutama industri kimia. Perusahaan industri kimia masih terbelenggu dengan bahan baku impor dimana pada tahun 2011 impor bahan baku industri ini sebesar US\$ 5,1 milliar, dan pada tahun 2014 lalu sebesar US\$17 milliar, dengan kondisi terjadinya depresiasi rupiah saat itu menjadikan biaya produksi industri meningkat tajam.

Masalah utama yang dialami industri yakni pada bahan baku, yang mana untuk mendapatkan bahan baku harus impor, dan harganya terus naik karena melemahnya rupiah. Tapi jika tidak impor maka tidak bisa berproduksi, otomatis pasti ada pengurangan produksi meski pun belum bisa diproyeksikan.Pada kesempatan yang sama, Direktur Jenderal Basis Industri Manufaktur, Kementrian Perindustrian, Harjanto, menambahkan, tahun ini pemerintah menargetkan pertumbuhan ekonomi sebesar 5,7\%. Jika ingin mengejar itu tentu, industri harus tumbuh di atas 7\% dan kalau bisa 9\% dari PDB karena ini akan mendorong peningkatan pertumbuhan ekonomi nasional. Salah satu yang bisa menopang dari hal ini adalah industri manufaktur. Peranan industri manufaktur, seperti industri kimia dasar ini sangat penting karena memang industri yang menyediakan bahan dasar untuk industri yang lain. Karena industri ini nantinya yang akan menopang industri lain, jika mereka tidak berproduksi maka industri lain akan jatuh (Harian Ekonomi Neraca, 2015).Terkait isu diatas, untuk mencapai pertumbuhan perusahaan industri dasar, tentu saja harus bisa menarik minat investor untuk masuk ke dalam sektor ini.Karena pertumbuhan tersebut ditopang oleh investasi yang tinggi, sehingga mampu mendorong pertumbuhan sesuai target atau bahkan bisa melebihi target. Dan untuk mendapatkan minat dari investor tentu saja perusahaan pada sektor ini harus menunjukkan kinerja perusahaan yang baik, yaitu salah satunya dengan menampilkan pertumbuhan laba yang berkualitas.

Berdasarkan uraian latar belakang diatas, dengan adanya fenomena dan hasil penelitian yang berbeda maka menunjukkan adanya research gap didalam penelitian sejenis. Research gap adalah kesenjangan penelitian yang perlu diteliti dan menjadi alasan bagi penulis untuk 
dijadikan objek penelitian. Oleh karena itu, peneliti ingin menguji kembali pengaruh book-tax differences dan likuiditas terhadap pertumbuhan laba, dengan menjadikan perusahaan subsektor manufaktur industri dasar dan kimia yang terdaftar di Bursa Efek Indonesia sebagai objek penelitian, dengan judul "Analisis Pengaruh Book-Tax Differences dan Likuiditas Terhadap Pertumbuhan Laba (Pada Perusahaan Subsektor Manufaktur Industri Dasar dan Kimia yang Terdaftar di Bursa Efek Indonesia Periode 2012-2015)

\section{LANDASAN TEORI}

\section{Teori Agensi (Agency Theory)}

Teori keagenan sudah menjadi dasar teori bagi banyak penelitian tentang akuntansi. Teori agensi berawal dengan adanya penekanan pada kontrak sukarela yang timbul di antara berbagai pihak organisasi sebagai suatu solusi yang efisien terhadap konflik kepentingan tersebut. Teori ini berubah menjadi suatu pandangan atas perusahaan sebagai suatu "penghubung (nexus) kontrak" melalui pernyataan oleh Jensen dan Meckling yang menyatakan bahwa perusahaan adalah "cerita fiksi legal yang berfungsi sebagai penghubung atas serangkaian hubungan kontrak antara individu". Dengan adanya perspektif "penghubung kontrak" terhadap perusahaan ini, teori biaya kontrak melihat peran informasi akuntansi sebagai pengamat dan penegak atas kontrak-kontrak ini untuk menurunkan biaya agensi dari konflik kepentingan tertentu (Belkoui, 2007:188).

Berdasarkan definisi yang telah disebutkan di atas dapat disimpulkan bahwa teori agensi adalah teori yang menyatakan adanya hubungan antara prinsipal yaitu investor atau pemegang saham dengan agen yaitu manajemen. Principal dan agen berusaha saling memenuhi kontrak dimana, perusahaan membayar gaji dalam bentuk natura dan kenikmatan, seperti biaya fasilitas sewa rumah direktur, biaya pengobatan, dan mobil dinas yang termasuk booktax, principalatau investor membayar agency cost seperti beban gaji tersebut untuk memastikan aset-aset yang dimilikinya aman dan memberikan return bagi investor.

\section{Pertumbuhan Laba (Income Growth)}

Menurut Ikatan Akuntansi Indonesia (2007:13), penghasilan bersih atau laba adalah sebagai ukuran kinerja atau sebagai dasar bagi ukuran yang lain seperti imbal hasil investasi (return on investment) atau laba per saham (earning per share), yang mana merupakan kenaikan manfaat ekonomi selama satu periode akuntansi dalam bentuk pemasukan atau penambahan aset atau penurunan kewajiban yang mengakibatkan kenaikan ekuitas yang tidak berasal dari kontribusi penanaman modal.

Dalam pengertian yang lain Belkoui (2006:226) menyatakan, Laba adalah hal yang mendasar dan penting dari laporan keuangan dan memiliki banyak kegunaan dalam berbagai konteks. Laba umumnya dipandang sebagai dasar untuk perpajakan, penentu dari kebijakan pembayaran dividen, panduan dalam melakukan investasi dan pengambilan keputusan, dan satu elemen dalam peramalan. Laba dianggap suatu sarana prediktif yang membantu dalam meramalkan laba dan peristiwa-peristiwa ekonomi dimasa depan. Didalam literatur lainpengertian laba menurut IAI dalam Febiyanto (2014), yaitu kenaikan manfaat ekonomi selama satu periode akuntansi dalam bentuk pemasukan atau penambahan aktiva atau penurunan kewajiban yang mengakibatkan kenaikan ekuitas yang tidak berasal dari kontribusi peranan modal. 


\section{Book-Tax Differences}

Book-tax differences merupakan perbedaan jumlah laba akuntansi dengan laba fiskal yang dihitung berdasarkan Standar Akuntansi Keuangan (SAK) dan peraturan perpajakan (Febiyanto,2014). Muljono (2006:144) menyatakan, yang membedakan antara laba secara komersil dengan penghasilan kena pajak atau laba fiskal adalah dilakukannya koreksi fiskal terhadap laba secara komersial.

Penyebab perbedaan laporan keuangan komersial dan laporan keuangan fiskal adalah karena terdapat perbedaan prinsip akuntansi, perbedaan metode dan prosedur akuntansi, perbedaan pengakuan penghasilan dan biaya, serta perbedaan perlakuan penghasilan dan biaya (Resmi, 2009). Menurut Standar Akuntansi Keuangan (SAK), tujuan laporan keuangan adalah menyediakan informasi yang menyangkut posisi keuangan, serta perubahan posisi keuangan suatu perusahaan yang bermanfaat bagi sejumlah besar pemakai dalam rangka pengambilan keputusan. Sementara tujuan sistem perpajakan adalah pemungutan pajak yang adil dan merupakan tanggung jawab Direktorat Jendral Pajak untuk melindungi para pembayar pajak dari tindakan yang semena-mena (Martani dan Persada, 2009). Beberapa prinsip yang berlaku umum (Standar Akuntansi Keuangan) yang telah diakui secara umum dalam dunia bisnis dan profesi tetapi tidak diakui dalam fiskal, yaitu prinsip konservatisme, prinsip harga perolehan, prinsip pemadanan biaya-manfaat (Resmi, 2009).

\section{Beda Tetap (permanent differences)}

Beda tetap terjadi karena adanya perbedaan pengakuan penghasilan dan beban menurut akuntansi dengan fiskal, yaitu adanya penghasilan dan beban yang diakui menurut akuntansi namun tidak diakui menurut fiskal, ataupun sebaliknya.Beda tetap mengakibatkan laba atau rugi menurut akuntansi (laba sebelum pajak/pre tax income) yang berbeda secara tetap dengan laba atau rugi menurut fiskal PhKP (taxable income).

\section{Beda Sementara (temporary differences)}

Menurut Agoes dan Trisnawati (2013:238) bahwa, beda sementara merupakan perbedaan perlakuan akuntansi dan perpajakan yang sifatnya temporer. Artinya, secara keseluruhan beban atau pendapatan akuntansi maupun perpajakan sebenarnya sama, tetapi tetap berbeda alokasi setiap tahunnya. Beda waktu biasanya timbul karena perbedaan metode yang dipakai antara fiskal dengan akuntansi dalam hal 1) Akrual dan realisasi; 2). Penyusutan dan amortisasi; 3). Penilaian persediaan; 4). Kompensasi kerugian fiscal Perbedaan temporer dimaksudkan sebagai perbedaan antara dasar pengenaan pajak (tax base) dari suatu aset atau kewajiban dengan nilai tercatat pada aset atau kewajiban yang berakibat pada perubahan laba fiskal periode mendatang (Waluyo, 2009:228).

\section{Rekonsiliasi Fiskal}

Rekonsiliasi (koreksi) fiskal adalah proses penyesuaian atas laba akuntansi yang berbeda dengan ketentuan fiskal untuk menghasilkan penghasilan neto atau laba yang sesuai dengan ketentuan perpajakan (Agoes \& Trisnawati,2013:237). Hampir semua perhitungan laba komersial yang dihasilkan oleh setiap perusahaan, harus mengalami koreksi fiskal untuk mendapatkan penghasilan kena pajak, karena tidak semua ketentuan dalam standar akuntansi keuangan digunakan dalam peraturan perpajakan atau sebaliknya. Menurut Muljono (2006:144), koreksi fiskal secara akuntansi tidak memerlukan perlakuan jurnal khusus 
karena pada prinsipnya koreksi fiskal tidak mengubah besarnya saldo pada rekening nominal atau rekening riil pada neraca maupun laporan laba rugi. Koreksi fiskal dapat berupa: 1) Koreksi Positif adalah koreksi fiskal yang mengakibatkan pengurangan biaya yang diakui dalam laporan laba rugi laba komersial semakin kecil, atau yang berakibat adanya penambahan penghasilan, 2) Koreksi Negatif adalah koreksi fiskal yang berakibat dengan adanya penambahan biaya yang telah diakui dalam laporan laba rugi komersial menjadi semakin besar, atau yang berakibat dengan adanya pengurangan penghasilan.

\section{Likuiditas}

Likuiditas adalah rasio yang menunjukkan kemampuan perusahaan dalam memenuhi kewajiban atau membayar utang jangka pendeknya. Menurut Hery (2016:151), informasi likuiditas dapat memberikan informasi mengenai kinerja keuangan perusahaan selama periode tertentu. Melalui informasi likuiditas, pihak manajemen dapat memantau ketersediaan jumlah kas khususnya terkait dengan pemenuhan kewajiban yang akan segera jatuh tempo. Selain pihak internal perusahaan, informasi likuiditas juga berguna bagi pihak eksternal perusahaan seperti investor dalam hal pembagian dividen tunai atas investasi yang telah dilakukan, selain itu kreditor juga sangat berkepentingan dengan informasi likuiditas perusahaan dalam hal dasar pertimbangan untuk pemberian kredit kepada perusahaan guna memperhitungkan kemampuan perusahaan dalam menghasilkan laba untuk mengembalikan pokok pinjaman beserta bunga yang akan didapatkan. Karena investor maupun kreditor biasanya akan menginvestasikan modal dan memberikan pinjaman atau kredit kepada perusahaan yang memiliki tingkat likuiditas yang baik.

\section{Pengembangan Hipotesis}

\section{Pengaruh Perbedaan Permanen Terhadap Pertumbuhan Laba}

Menurut Windarti (2014) semakin tinggi perbedaan permanen maka pertumbuhan laba perusahaan akan semakin besar. Beda permanen sebagai salah satu pembentuk book-tax differences dapat mempengaruhi besar kecilnya laba bersih yang dihasilkan oleh perusahaan. Hal tersebut didukung oleh penelitian yang dilakukan oleh Purnama, Pratomo, dan Priyanto (2016) yang menyatakan bahwa perbedaan permanen berpengaruh secara signifikan terhadap pertumbuhan laba. Berdasarkan uraian teori dan penelitian sebelumnya, maka pengembangan hipotesis bahwa perbedaan temporer sebagai salah satu pembentuk book-tax differences berpengaruh terhadap pertumbuhan laba suatu perusahaan.

$\mathrm{H}_{1}$ : Diduga perbedaan permanen berpengaruh terhadap pertumbuhan laba

\section{Pengaruh Perbedaan Temporer Terhadap Pertumbuhan Laba}

Windarti (2014) juga berpendapat bahwa, perbedaan temporer sebagai salah satu pembentuk book-tax differences sama dengan perbedaan permanen, dalam halnya mempengaruhi pertumbuhan laba perusahaan. Hal tersebut didukung oleh Brolin dan Rohman (2014), yang menyatakan melalui hasil penelitiannya bahwa perbedaan temporer berpengaruh signifikan terhadap pertumbuhan laba. Hal ini menunjukkan bahwa perbedaan temporer yang merupakan komponen pembentuk book tax differences berpengaruh terhadap pertumbuhan laba. Perusahaan dengan perbedaan temporer yang lebih besar akan memiliki pertumbuhan laba yang lebih besar. Berdasarkan uraian teori dan penelitian sebelumnya, maka peneliti mengajukan pengembangan hipotesis bahwa perbedaan temporer sebagai salah satu pembentuk book-tax differences berpengaruh terhadap pertumbuhan laba suatu perusahaan.

$\mathrm{H}_{2}$ : Diduga perbedaan temporer berpengaruh terhadap pertumbuhan laba 


\section{Pengaruh Working Capital To Total Asset Terhadap Pertumbuhan Laba}

Menurut Kasmir (2015:221) Rasio likuiditas atau sering disebut dengan rasio modal kerja merupakan rasio yang digunakan untuk mengukur seberapa likuidnya perusahaan. Working capital to total asset yang merupakan modal kerja bersih dari total aset perusahaan dapat mendukung operasional perusahaan. Dimana penambahan modal kerja didapatkan dari pinjaman perusahaan, dan modal kerja tersebut digunakan untuk kegiatan operasional. Dengan modal kerja yang besar perusahaan dapat meningkatkan aset yang dimiliki perusahaan sehingga kegiatan operasional perusahaan dapat berjalan semakin baik. Kegiatan operasional yang baik akan meningkatkan penjualan perusahaan sehingga kemampuan perusahaan dalam menghasilkan laba juga akan meningkat (Purnama, Pratomo \& Priyatno:2016). Runy (2002) juga berpendapat yang dalam Yusuf (2013) bahwa semakin besar WCTA akan meningkatkan laba yang selanjutnya akan mempengaruhi peningkatan pertumbuhan laba. Hal ini dikarenakan efisiensi dari selisih antara aktiva lancar (current assets) dan hutang lancar (current liabilities).

Hasil penelitian Takarini dan Ekawati (2003) menunjukkan bahwa WCTA berpengaruh terhadap pertumbuhan laba satu tahun yang akan datang, dalam penelitian yang lain yaitu Yusuf (2013) juga menunjukkan bahwa WCTA secara parsial berpengaruh terhadap Perubahan Laba. Berdasarkan uraian teori dan penelitian sebelumnya, maka peneliti mengajukan pengembangan hipotesis bahwa rasio likuiditas dengan proksi working capital to total asset (WCTA) mempunyai pengaruh yang signifikan positif terhadap pertumbuhan laba suatu perusahaan.

H3 : Diduga Working Capital To Total Asset (WCTA) berpengaruh terhadap pertumbuhan laba.

\section{Pengaruh Perbedaan Permanen, Perbedaan Temporer, dan Working Capital To Total Asset Terhadap Pertumbuhan Laba}

Hasil penelitian yang dilakukan Purnama, Pratomo dan Priyanto (2016) menunjukan secara simultan atau secara bersama-sama variabel independen yaitu book tax differences dengan komponen perbedaan permanen dan perbedaan temporer, dan likuiditas yang diwakilkan dengan working capital to total asset berpengaruh signifikan terhadap pertumbuhn laba suatu perusahaan. Berdasarkan uraian hasil penelitian sebelumnya, maka peneliti mengajukan pengembangan hipotesis, yaitu:

$\mathrm{H} 4$ : Diduga perbedaan permanen, perbedaan temporer, dan working capital to total asset secara simultan berpengaruh terhadap pertumbuhan laba.

\section{METODOLOGI PENELITIAN}

\section{Obyek dan Ruang Lingkup Penelitian}

Objek yang dipilih untuk melakukan penelitian ini adalah perusahaan manufaktur subsektor industri dasar dan kimia yang terdaftar di Bursa Efek Indonesia. Sedangkan lingkup penelitian dalam penelitian ini merupakan laporan keuangan perusahaan manufaktur subsektor industri dasar dan kimia yang terdaftar di Bursa Efek Indonesia (BEI) periode 2012 hingga 2015.

\section{Metode Penelitian}

Penelitian ini merupakan penelitian kuantitatif, termasuk dalam penelitian descripsion quantitative yang menggambarkan objek penelitian pada saat ini berdasarkan fakta-fakta, kemudian dianalisis dan diinterpretasikan (Siregar, 2013). Dalam penelitian ini peneliti menggunakan data sekunder. Data sekunder adalah data yang diterbitkan atau digunakan oleh 
organisasi yang bukan pengolahnya (Siregar, 2013). Data sekunder yang digunakan peneliti merupakan data yang dipublikasikan oleh Bursa Efek Indonesia melalui situs www.idx.co.id.

\section{Operasionalisasi Variabel \\ Variabel Terikat (Dependent Variable)}

Variabel terikat dalam penelitian ini adalah Pertumbuhan Laba (Income Growth). Laba merupakan ukuran kinerja dari suatu perusahaan secara keseluruhan. Dalam penelitian ini, peneliti mengacu kepada penelitian Hapsari (2007) dalam menggunakan laba setelah pajak (Earning After Tax), untuk menghitung pertumbuhan laba perusahaan Lestari (2011),

\section{Variabel Bebas (Independent Variable)}

Variabel bebas (Independen) adalah variabel yang menjadi sebab atau berubah/memengaruhi suatu variabel lain (variabel dependen) (Siregar, 2013). Ataupun variabel yang mempengaruhi variabel terikat baik secara secara positif atau negatif. Dalam penelitian ini yang menjadi variabel independen adalah book-tax differences atau perbedaan antara laba akuntansi dan laba fiskal yang terbagi menjadi dua komponen yaitu perbedaan permanen (permanent differences) dan perbedaan temporer (temporary differences), kemudian variabel independen yang lainnya adalah rasio likuiditas yang diproksikan dengan working capital to total asset (WCTA).

\section{Perbedaan permanen (permanent differences)}

Perbedaan permanen diperoleh dari jumlah perbedaan permanen yang tersaji pada catatan atas laporan keuangan dibagi dengan total asset (Rosanti, 2013). Perbedaan permanen terdiri dari penghasilan yang telah dipotong PPh final, penghasilan yang bukan merupakan objek pajak, pengeluaran yang termasuk dalam non deductible expense dan tidak termasuk dalam deductible expense. Menurut Brolin dan Rohman (2014), Perbedaan permanen sebagai pembentuk book tax differences menyebabkan adanya koreksi fiskal baik positif maupun negatif. Koreksi positif menyebabkan laba fiskal bertambah. Jika laba fiskal bertambah maka beban pajak pajak yang harus dibayarkan akan semakin besar. Semakin besar beban pajak yang harus dibayarkan maka semakin kecil laba bersih yang dihasilkan. Koreksi negatif menyebabkan laba fiskal berkurang sehingga beban pajak yang harus dibayarkan semakin kecil. Beban pajak yang semakin kecil membuat laba bersih menjadi semakin besar.

\section{Perbedaan temporer (temporary differences)}

Perbedaan temporer diperoleh dari jumlah perbedaan temporer yang terdapat pada catatan atas laporan keuangan dibagi dengan total asset (Rosanti, 2013).Contoh perbedaan temporer yaitu penyusutan, dalam akuntansi komersial pembebanan biaya penyusutan dilakukan berdasarkan umur ekonomis suatu aset, tetapi dalam akuntansi perpajakan, pembebanan biaya penyusutan dilakukan berdasarkan golongan kelompok. Contoh lainnya adalah penilaian persediaan, dan penghapusan piutang.

\section{Working Capital To Total Asset (WCTA)}

Rasio ini diperoleh dari perbandingan modal kerja bersih, yaitu aktiva lancar dikurangi dengan kewajiban lancar dan dibagi dengan total aktiva yang terdapat dalam laporan keuangan perusahaan pada bagian neraca. Alasan peneliti menggunakan modal kerja sebagai salah satu indikator dalam penelitian ini yaitu dalam menjalankan kegiatan operasional perusahaan memerlukan modal kerja untuk dapat beroperasi, dari kegiatan operasional ini perusahaan 
menghasilkan produk untuk dijual, kemudian penjualan yang meningkat akan menghasilkan laba bagi perusahaan. Peneliti memformulasikan WCTA yang merujuk pada penelitian Yusuf (2014).

\section{Teknik Penentuan Populasi danSampel}

Populasi dalam penelitian ini adalah perusahaan subsektor manufaktur industri dasar dan kimia yang terdaftar di Bursa Efek Indonesia periode 2012-2015. Sedangkan Sampel adalah bagian dari populasi yang akan diteliti dan dianggap dapat menggambarkan atau mewaakili populasinya. Metode pengambilan sampel dalam penelitian ini adalah dengan teknik purposive sampling yakni metode penetapan responden untuk dijadikan sampel berdasarkan pada kriteria-kriteria tertentu.

Penggunaan metode ini bertujuan untuk mendapatkan sampel yang representatif dengan kriteria yang telah ditetapkan. Adapun kriteria sampel dalam penelitian ini adalah: 1) Perusahaan subsektor manufaktur industri dasar dan kimia yang terdaftar di Bursa Efek, 2) Indonesia periode 2012-2015, 3) Perusahaan tidak mengalami kerugian selama periode penelitian yaitu dari tahun 2012 sampai 2015, 4) Perusahaan mempublikasikan laporan keuangan dalam mata uang rupiah, 5) Perusahaan mempublikasikan laporan keuangan secara berturut-turut selama periode penelitian, 5) Perusahaan yang menampilkan data lengkap didalam catatan atas laporan keuangan perusahaan seperti perbedaan permanen dan perbedaan temporer selama periode penelitian.

\section{Metode Analisis Data dan Pengujuan Hipotesis}

Analisis Statistik Deskriptif, Menurut Siregar (2013:2), statistik deskriptif adalah statistik yang berkenaan dengan bagaimana cara mendeskripsikan, menggambarkan, menjabarkan, atau menguraikan data agar mudah dipahami. Pengukuran statistik deskriptif yang digunakan dalam penelitian ini adalah mean, standar deviasi, maksimun dan minimum. Analisis statistik deskriptif digunakan untuk menyajikan dan menganalisis data disertai dengan perhitungan agar dapat memperjelas keadaan atau karakteristik data yang bersangkutan, Kemudian dilanjutkan Uji Asumsi Klasik, antara lain : uji normalitas, Uji Heteroskedastisitas, Uji Multikolonieritas, Uji Autokorelasi

Pengujuain linear berganda digunakan untuk menguji perbedaan permanen, perbedaan temporer dan working capital to total asset terhadap pertumbuhan laba. Kemudian pengujian Koefisien determinasi pada intinya mengukur seberapa jauh kemampuan model dalam menerangkan variasi variabel dependen, pengujian secara simultan menggunakan distribusi $F$, yaitu membandingkan antara Fhitung dan Ftabel. Uji $f$ menguji secara bersama-sama (simultan) pengaruh perbedaan permanen, perbedaan temporer dan working capital to total asset terhadap pertumbuhan laba perusahaan.

Uji hipotesis menggunakan uji parsial dengan uji t untuk menentukan signifikan atau tidak signifikan masing-masing nilai koefisien regresi ( $b_{1}$ dan $b_{2}$ ) secara sendiri-sendiri terhadap variabel terikat (Sunyoto, 2011:13). Pengujian ini dilakukan berdasarkan perbandingan nilai $\mathrm{t}$ (two tailed) hitung masing-masing koefisien regresi dengan nilai $t$ tabel dengan tingkat signifikansi $5 \%$ dengan derajat kebebasan $\mathrm{df}=(\mathrm{n}-\mathrm{k})$, dimana $\mathrm{n}$ adalah jumlah sampel dan $\mathrm{k}$ adalah jumlah variabel independen dan dependen. 


\section{HASIL DAN PEMBAHASAN}

Hasil analisis statistik deskriptif menggambarkan banyaknya jumlah sampel (N) yaitu 64 pengamatan yang merupakan keseluruhan total sampel pada periode penelitian tahun 2012 sampai dengan tahun 2015. Perusahaan dijadikan sampel dalam penelitian sebanyak 16 perusahaan dengan periode penelitian sebanyak 4 tahun, sehingga diperoleh jumlah sampel selama 4 tahun dengan total 64 pengamatan.

Uji normalitas menggunakan uji one-sample kolmogrorov-smirnov yang ditampilkan pada Tabel 4.4. dapat diketahui bahwa untuk model penelitian pertumbuhan laba sebagai variabel dependen menunjukkan nilai asymp. sig. (2-tailed) sebesar 0,729 lebih tinggi dari tingkat probabilitas $5 \%$ atau nilai $\alpha=0,05$ yang mengindikasikan bahwa model penelitian ini berdistribusi normal.

Nilai signifikansi untuk semua variabel dependen atau variabel bebas bahwa, semua nilai probabilitas signifikansinya diatas $5 \%$. Baik pada variabel perbedaan permanen 0,978 $>0,05$, perbedaan temporer $0,724>0,05$, dan working capital to total asset $0,160>0,05$, semuanya memiliki nilai signifikansi diatas $5 \%$ atau 0,05 . Maka model penelitian terbebas dari masalah heteroskedastisitas, dimana setiap variabel dependen (perbedaan permanen, perbedaan temporer, dan working capital to total asset) lebih tinggi dari nilai $\alpha=0,05$.

Dari uji tersebut diketahui bahwa untuk model penelitian dengan pertumbuhan laba sebagai variabel dependen menunjukkan semua variabel independen yang terdiri dari perbedaan permanen, perbedaan temporer, dan working capital to total asset memiliki nilai tolerance $>0,10$ dan nilai VIF $<10$, maka dapat diartikan bahwa model penelitian terbebas dari masalah multikolinearitas. Hasil uji autokorelasi model penelitian menggunakan uji Run testmenghasilkan nilai asymp. sig. (2-tailed) sebesar 0,450 lebih tinggi dari nilai $a=0,05$, sehingga dapat disimpulkan bahwa residual bersifat random (acak) atau tidak terjadi autokorelasi antar nilai residual. Maka model regresi terbebas dari autokorelasi.

\section{Analisis Model Regresi dan Koefisien Determinasi}

Regresi berganda bertujuan untuk menguji hubungan pengaruh antara satu variabel terhadap variabel lain. Hasil pengujian regresi berganda untuk model penelitian dengan menggunakan program SPSS 21. Hasil Persamaan Regresi Berganda dapat diketahui persamaan regresi untuk model sebagai berikut :

$$
Y=0,105-12,795 X_{1}+4,327 X_{2}-0,693 X_{3}+\varepsilon
$$

1) Constant $=0,105$. Hal ini berarti jika variabel independen (perbedaan permanen, perbedaan temporer, dan working capital to total asset) konstan atau tetap, maka pertumbuhan laba sebesar 0,105 satuan.

2) Koefisien $\beta_{1}=-12,795$. Hal ini berarti jika perbedaan permanen $\left(X_{1}\right)$ meningkat 1 satuan maka pertumbuhan laba menurun sebesar 12,795 satuan.

3) Koefisien $\beta_{2}=4,327$. Hal ini berarti jika perbedaan temporer $\left(X_{2}\right)$ meningkat 1 satuan maka pertumbuhan laba akan meningkat sebesar 4,327 satuan.

4) Koefisien $\beta_{3}=-0,693$. Hal ini berarti jika working capital to total asset ( $X_{3}$ ) meningkat 1 satuan maka pertumbuhan laba akan menurun sebesar 0,693 satuan. 
Hasil statistik $F$ pada model penelitian menyajikan bahwa nilai $f$ hitung sebesar 22,100 dengan probabilitas 0,000 pada tingkat signifikansi yang digunakan peneliti 0,05 atau $5 \%$. Dengan nilai Fhitung sebesar 22,100 $>$ Ftabel 2,75. Karena nilai probabilitas lebih kecil daripada 0,05 mengindikasikan bahwa model penelitian dengan variabel independen yang terdiri dari perbedaan permanen, perbedaan temporer, dan working capital to total asset secara bersama-sama dapat mempengaruhi pertumbuhan laba.

Tabel 1 Hasil Uji F

\begin{tabular}{rlrrrrr}
\multicolumn{7}{c}{ ANOVA $^{\mathrm{a}}$} \\
Model & \multicolumn{1}{c}{$\begin{array}{c}\text { Sum of } \\
\text { Squares }\end{array}$} & Df & $\begin{array}{c}\text { Mean } \\
\text { Square }\end{array}$ & F & Sig. \\
\hline \multirow{2}{*}{1} & Regression & 9.407 & 3 & 3.136 & 22.100 & $.000^{\mathrm{b}}$ \\
\cline { 2 - 7 } & Residual & 8.513 & 60 & 3.136 & & \\
& Total & 17.921 & 63 & .142 & & \\
\hline
\end{tabular}

a. Dependent Variable: $Y$

b. Predictors: (Constant), X3, X2, X1

Sumber : Data sekunder yang diolah, 2016

Uji Koefisien Determinasi $\left(R^{2}\right)$ menjelaskan seberapa besar kemampuan variabel independen menjelaskan variabel dependen. Nilai koefisien determinasi dalam regresi linear berganda ditunjukkan dengan adjusted karena telah disesuaikan dengan jumlah variabel independen yang digunakan dalam regresi linear berganda. Hasil nilai adjusted dari variabel independen perbedaan permanen, perbedaan temporer, dan working capital to total asset terhadap pertumbuhan laba perusahaan sebagai variabel dependen diperoleh sebesar 0,501. Hal ini bermakna bahwa hanya $50,1 \%$ variabel dependen atau variabel pertumbuhan laba mampu dijelaskan oleh variabel independen dalam penelitian ini yaitu perbedaan permanen, perbedaan temporer dan working capital to total asset. Sisanya 49,9\% dijelaskan oleh variabel lain yang tidak diteliti dalam penelitian ini.

Tabel ...... Hasil Uji Koefisien

Determinasi Model Summary

\begin{tabular}{|c|c|c|c|c|}
\hline Model & $\mathrm{R}$ & R Square & $\begin{array}{l}\text { Adjusted R } \\
\text { Square }\end{array}$ & $\begin{array}{l}\text { Std. Error of the } \\
\text { Estimate }\end{array}$ \\
\hline 1 & $.725^{a}$ & .525 & .501 & .376682435056 \\
\hline
\end{tabular}

\section{Analisis Uji Hipotesis}

\section{Hasil Uji Hipotesis Penelitian}

Uji regresi linear berganda akan menguji pengaruh variabel independen perbedaan permanen, perbedaan temporer, dan working capital to total asset, dan pertumbuhan laba sebagai variabel dependen. Berikut ini adalah hasil dari pengujian hipotesis model regresi linear berganda pada tabel berikut: 


\begin{tabular}{|c|c|c|c|c|c|c|}
\hline Tabel. 2. Hasil Uji T & \multicolumn{6}{|c|}{ Coefficients $^{a}$} \\
\hline \multirow{2}{*}{\multicolumn{2}{|c|}{ Model }} & \multicolumn{2}{|c|}{$\begin{array}{l}\text { Unstandardized } \\
\text { Coefficients }\end{array}$} & \multirow{2}{*}{$\begin{array}{l}\text { Standardized } \\
\text { Coefficients } \\
\text { Beta }\end{array}$} & \multirow[t]{2}{*}{$t$} & \multirow[t]{2}{*}{ Sig } \\
\hline & & B & Std. Error & & & \\
\hline 1 & (Constant) & .105 & .079 & & 1.343 & .184 \\
\hline & $\mathrm{X} 1$ & -12.795 & 1.589 & -.802 & -8.051 & .00 \\
\hline & $\mathrm{X} 2$ & 4.327 & 4.558 & .088 & .949 & .346 \\
\hline & X3 & -.693 & .243 & -.283 & -2.849 & .006 \\
\hline
\end{tabular}

\section{Hasil Penelitian}

Berdasarkan pengujian yang telah dilakukan oleh peneliti, maka dalam hal ini peneliti akan menjelaskan secara lebih rinci pada pembahasan hasil uji hipotesis. Adapun pembahasan dari setiap hipotesis dalam penelitian ini adalah sebagai berikut :

Hipotesis pertama yang diajukan oleh peneliti adalah perbedaan permanen berpengaruh terhadap pertumbuhan laba pada perusahaan manufaktur subsektor industri dasar dan kimia yang terdaftar di BEI periode 2012-2015. Berdasarkan hasil pengujian yang dilakukan oleh peneliti dapat dibuktikan bahwa hipotesis pertama dapat diterima dengan hasil penelitian bahwa perbedaan permanen berpengaruh terhadap pertumbuhan laba. Beda permanen berpengaruh terhadap pertumbuhan laba pada perusahaan manufaktur subsektor industri dasar dan kimia yang terdaftar di Bursa Efek Indonesia (BEI) tahun 2012-2015. Hal ini ditunjukkan dari hasil uji t variabel beda permanen, dimana -thitung sebesar $-8,051$ dan signifikansi sebesar 0,000 . Jika dibandingkan dengan -ttabel sebesar -1,67065, maka -thitung<-ttabel dan Sig $<0,05$, sehingga $\mathrm{H}_{1}$ diterima. Hal ini dapat maknai bahwa semakin besar jumlah perbedaan permanen terhadap total asset yang dimiliki perusahaan, maka pertumbuhan laba perusahaan akan semakin kecil.

Beda permanen sebagai salah satu pembentuk book-tax differences dapat mempengaruhi besar kecilnya laba bersih yang dihasilkan perusahaan. Hal ini disebabkan adanya koreksi fiskal yang dilakukan terhadap perbedaan tersebut, baik koreksi positif maupun koreksi negatif. Koreksi positif mengkibatkan laba fiskal bertambah, semakin besar laba fiskal maka beban pajak yang harus dibayarkan akan semakin besar pula dan akibatnya laba bersih yang dihasilkan perusahaan akan berkurang. Sedangkan koreksi negatif mengakibatkan laba fiskal berkurang, semakin kecil laba fiskal maka beban pajak yang harus dibayarkan akan semakin kecil pula dan akibatnya laba bersih yang dihasilkan perusahaan akan bertambah. Sehingga beda permanen berpengaruh terhadap pertumbuhan laba.

Hasil ini mendukung penelitian sebelumnya yang dilakukan oleh Purnama, Pratomo dan Triyanto (2016), yang mengungkapkan bahwa perbedaan permanen berpengaruh terhadap pertumbuhan laba suatu perusahaan. Jackson (2009) juga mengungkapkan dalam jurnalnya bahwa beda permanen berpengaruh signifikan terhadap pertumbuhan laba.

Hipotesis kedua yang diajukan oleh peneliti adalah perbedaan temporerberpengaruh terhadap pertumbuhan laba pada perusahaan manufaktur subsektor industri dasar dan kimia yang terdaftar di BEI periode 2012-2015. Berdasarkan hasil pengujian yang dilakukan oleh peneliti dapat dibuktikan bahwa hipotesis kedua tidak dapat diterima dengan hasil penelitian bahwa perbedaan temporer tidak berpengaruh terhadap pertumbuhan laba ditunjukkan dari hasil uji t variabel beda temporer, dimana thitung sebesar 0,949 dan signifikansi sebesar 
0,346. Jika dibandingkan dengan ttabel sebesar 1,67065, maka thitung< tabel dan Sig > 0,05 , sehingga $\mathrm{H}_{2}$ ditolak. Hal ini disebabkan karena perbedaan temporer pada penelitian ini didominasi oleh perbedaan temporer dengan koreksi positif.

Hipotesis ketiga yang diajukan oleh peneliti adalah working capital to total asset berpengaruh terhadap pertumbuhan laba pada perusahaan manufaktur subsektor industri dasar dan kimia yang terdaftar di BEI periode 2012-2015. Berdasarkan hasil pengujian yang dilakukan oleh peneliti dapat dibuktikan bahwa hipotesis ketiga dapat diterima dengan hasil penelitian bahwa working capital to total asset berpengaruh terhadap pertumbuhan laba. Working capital to total asset berpengaruh terhadap pertumbuhan laba pada perusahaan manufaktur subsektor industri dasar dan kimia yang terdaftar di Bursa Efek Indonesia (BEI) tahun 2012-2015. Hal ini ditunjukkan dari hasil uji t variabel Working capital to total asset, dimana -thitung sebesar $-2,849$ dan signifikansi sebesar 0,006 . Jika dibandingkan dengan ttabel sebesar -1,67065 maka -thitung < - ttabel dan $\mathrm{Sig}<0,05$, sehingga $\mathrm{H} 3$ diterima. Hal ini sejalan dengan hasil penelitian yang dilakukan oleh Yusuf (2013) yang menyatakan bahwa working capital to total asset berpengaruh terhadap pertumbuhan laba.

Berdasarkan analisis statistik dalam penelitian ini yang telah dilakukan di ketahui bahwa hipotesis keempat $\mathrm{H}_{4}$ (Diduga perbedaan permanen, perbedaan temporer, dan working capital to total asset berpengaruh terhadap pertumbuhan laba pada perusahaan industri dasar dan kimia diterima dengan nilai signifikan $0,000<0,05$ maka dapat disimpulkan bahwa erbedaan permanen, perbedaan temporer, dan working capital to total asset secara bersama-sama berpengaruh terhadap pertumbuhan laba, dan nilai Adjustedsebesar 0,501 atau $50,1 \%$. hal ini berarti variabel independen secara simultan dapat menjelaskan variabel dependen sebesar $50,1 \%$, sedangakan sisanya $49,9 \%$ ditentukan oleh variabel lain diluar model regresi.

\section{Kesimpulan}

Berdasarkan hasil analisis data penelitian dan pembahasan yang telah dilakukan, maka dapat disimpulkan sebagai berikut:

1. Bahwa perbedaan permanen, perbedaan temporer, dan working capital to total aset secara bersama-sama berpengaruh terhadap pertumbuhan laba pada perusahaan manufaktur subsektor industri dasar dan kimia yang terdaftar di Bursa Efek Indonesia (BEI) tahun 2012-2015.

2. Perbedaan permanen berpengaruh terhadap pertumbuhan laba pada perusahaan manufaktur subsektor industri dasar dan kimia yang terdaftar di Bursa Efek Indonesia (BEI) tahun 2012-2015.

3. Perbedaan temporer tidak berpengaruh terhadap pertumbuhan laba pada perusahaan manufaktur subsektor industri dasar dan kimia yang terdaftar di Bursa Efek Indonesia (BEI) tahun 2012-2015.

4. Working capital to total asset berpengaruh terhadap pertumbuhan laba pada perusahaan manufaktur subsektor industri dasar dan kimia yang terdaftar di Bursa Efek Indonesia (BEI) tahun 2012-2015. 


\section{Saran,}

1. Berdasarkan hasil dari penelitian yang telah disimpulkan diatas, maka penelitian selanjutnya diharapkan untuk dapat menambah variabel lain yang tidak diteliti dalam penelitian ini seperti arus kas operasi perusahaan.

2. Bagi peneliti selanjutnya untuk dapat menggunakan alat ukur yang berbeda khususnya untuk variabel perbedaan permanen dan perbedaan temporer yang mewakili book-tax differences.

\section{DAFTAR PUSTAKA}

Agoes, S., \& Trisnawati, E. (2013), Akuntansi Perpajakan (Edisi III). Jakarta: Salemba Empat. Belkoui, Ahmed Riahi. 2007. Accounting Theory (Teori Akuntansi). Jakarta: Salemba Empat.

Brolin, A.R., dan Rohman. A. (2014), Pengaruh book-tax differences terhadap pertumbuhan laba. Diponegoro Journal of Accounting. Volume 03 Nomor 02 Tahun Hal: 1-13.

Budi, Triton Prawira (2006), SPSS 13.0 Terapan Riset Statistik Parametrik.Yogyakarta: Andi.

Dewi, N.P.L., dan Putri, I. A. D.Pengaruh (2015), Book-Tax Difference, Arus Kas Operasi, Arus Kas Akrual, Dan Ukuran Perusahaan Pada Persistensi Laba. Ejurnal Universitas Udayana Bali. Vol.10, No.1 Tahun hal : $244-260$.

Fitri, Dinel (2014), Pengaruh Book-Tax Differences Terhadap Pertumbuhan Laba (Studi empiris pada Perusahaan Manufaktur yang terdaftar di BEI).Skripsi.Universitas Negeri Padang.

Febiyanto, Pradipta (2014), Pengaruh Perbedaan Laba Akuntansi Dan Laba Fiskal (BookTax Differences) Terhadap Pertumbuhan Laba(Studi Empiris pada Perusahaan Manufaktur yang Terdaftar di Bursa Efek Indonesia Tahun 2009-2011).Skripsi. Universitas Diponegoro.

Ghozali, Imam (2013), Aplikasi Analisis Multivariate Dengan Program IBM SPSS 21, Cetakan Ketujuh. Semarang: Badan Penerbit Universitas Diponegoro.

Hapsari, Epi A. (2007), Anlisis Rasio Keuangan Untuk Memprediksi Pertumbuhan Laba (Studi Kasus: Perusahaan Manufaktur yang terdaftar di Bursa Efek Jakarta periode 2001 sampai dengan 2005). Skripsi.Universitas Diponegoro.

Herry (2016), Analisis Laporan Keuangan Integrated and Comprehensive Edition. Jakarta: Grasindo.

Ikatan Akuntan Indonesia (2009), Standar Akuntansi Keuangan PSAK No. 1. Jakarta: Salemba Empat.

Jakarta: Salemba Empat. (2007), Standar Akuntansi Keuangan Per 1 September 2007.

Jackson, M. (2009), Book-Tax Differences And Earnings Growth. The Accounting Journal America, 1 - 75. University of Nevada.

Kasmir (2015), Analisis Laporan Keuangan. Jakarta: Rajawali.

Mardiasmo.(2005), Perpajakan Edisi Revisi (Ed.XIII). Yogyakarta: Andi.

Muljono, Djoko (2012), Pengaruh Perpajakan Pada Penerapan Standar Akuntansi Keuangan

Entitas Tanpa Akuntabilitas Publik. Yogyakarta: ANDI. (2006), Akuntansi Pajak. Yogyakarta: ANDI.

Priyatno, Duwi (2011), Buku Saku Analisis Statistik Data dengan SPSS. Yogyakarta: MediaKom. 
Purnama, A., Pratomo, D., \& Triyanto (2016), Pengaruh Book Tax Differences Dan Likuiditas Terhadap Pertumbuhan Laba (Studi pada Perusahaan Property dan Real Estate yang Terdaftar di Bursa Efek Indonesia Tahun 2010 -2014). Telkom University.

Resmi, S. (2009).Perpajakan (Teori Dan Kasus). Jakarta: Salemba Empat.

Rosanti, Aini N. Zulaikha. (2013). Pengaruh Book Tax Difference terhadap Perubahan Laba. Jurnal Akuntansi Universiats Diponegoro: Semarang.

Saputro, Adi N (2011), Pengaruh Book-Tax Differences Terhadap Pertumbuhan Laba (Studi Empiris Pada Perusahaan Manufaktur Yang Terdaftar Di Bursa Efek Indonesia Tahun 2008 - 2010). Skripsi. Universitas Diponegoro.

Siregar, S. (2013), Metode Penelitian Kuantitatif. Jakarta:

Prenadamediagroup. Sunyoto, D. (2011), Analisis Regresi Dan Uji

Hipotesis. Yogyakarta: CAPS. Waluyo.(2009). Akuntansi Pajak (Ed.II). Jakarta: Salemba Empat.

Wibowo, H., A., \& Pujiati, D. Analisis Rasio Keuangan Dalam Memprediksi Perubahan Laba Pada Perusahaan Real Estate Dan Properti Di Bursa Efek Indonesia (BEI) Dan Singapura (SPX). The Indonesian Accounting Review.Vol.1, No.2.Sekolah Tinggi IImu Ekonomi Perbanas Surabaya. Hal 155-178.

Windarti, Ratih E. (2014), Pengaruh Book Tax Differences dan Arus Kas Terhadap Pertumbuhan Laba (Studi Empiris Pada Perusahaan Manufaktur yang Terdaftar di Bursa Efek Indonesia Tahun 2011-2013).Jurnal Ekonomi dan Bisnis Universitas Islam Negeri Maulana Malik Ibrahim.Semarang.

Yusuf, Ario (2013), Analisis Pengaruh Rasio Keuangan TerhadapPerubahan Laba Pada Perusahaan ManufakturYang Terdaftar di Bursa Efek Indonesia. Skripsi. Universitas Lampung.

Zanora, Verty (2012), Pengaruh Likuidas, Leverage dan Aktivitas Terhadap Pertumbuhan Laba.Jurnal Akuntansi. Universitas Padang 